Dr VLADIMIR GEIGER, znanstveni savjetnik

Hrvatski institut za povijest

Zagreb, Opatička 10, Republika Hrvatska

geiger@isp.hr

originalan naučni rad

UDK 323.281(497.12)"1945"(093.2)

primljeno: 25. februar 2016.

726.821.025.2:341.322.5(497.12)"1945"(093.2)

prihvaćeno: 20. april 2016.

\title{
PROVOĐENJE ODLUKE OD 18. MAJA 1945. O UKLANJANJU VOJNIH GROBALJA I GROBOVA „OKUPATORA“ I „NARODNIH NEPRIJATELJA“ U SLOVENIJI
}

APSTRAKT: Namjera potpunog i radikalnog obračuna jugoslavenskih komunista s neprijateljem neposredno po završetku Drugoga svjetskog rata bila je i odluka Ministarstva unutrašnjih poslova Demokratske Federativne Jugoslavije od 18. maja 1945. o uklanjanju grobalja i grobova "okupatora" i "narodnih neprijatelja", koja je obuhvatila groblja i nadgrobne spomenike vojnika njemačke, talijanske i mađarske vojske te ustaše, četnike i slovenske domobrane. Nakon Drugoga svjetskog rata u Jugoslaviji, i Sloveniji, grobovi i groblja poginulih partizana i grobovi i groblja žrtava "fašističkog terora" zakonima su bili zaštićeni i uređivani i održavani, a grobovi i groblja "neprijateljskih" vojnika i grobovi „suradnika okupatora" ostali su izvan zakona. I tako je bilo sve do raspada SFRJ.

KLJUČNE RIJEČI: Slovenija, 1945., Odluka o uklanjanju grobalja i grobova „okupatora“ i „narodnih neprijatelja“, komunistička represija

Dugotrajnost i intenzitet Drugoga svjetskog rata na području Slovenije i prisutnost okupacijskih snaga Njemačkog Reicha, Italije i Mađarske te djelovanje slovenskih nacionalnih vojnih i poluvojnih snaga, jugoslavenskih monarhista i komunistima predvođenog partizanskog pokreta imalo je za posljedicu izravne sukobe zaraćenih strana, što je dovelo i do velikih ljudskih gubitaka i među vojnicima i među stanovništvom. Nepomirljive ideologije i politički i vojni interesi suprotstavljenih strana u ratnom sukobu i građanskom ratu umnožili su ljudske gubitke. ${ }^{1}$

${ }^{1}$ Usp. Vida Deželak Barič, „Posledice vojnega nasilja. Smrtne žrtve druge svetovne vojne in zaradi nje na Slovenskem“, u: Nasilje vojnih i povojnih dni, uredila Nevenka Troha (Ljubljana: Inštitut za novejšo zgodovino, 2014), 11-46. I ondje navedeni izvori i literatura. 
Odluka Ministarstva unutrašnjih poslova Demokratske Federativne Jugoslavije br. 1253 od 18. maja 1945. o uklanjanju i uništavanju grobalja i grobova „okupatora" i "narodnih neprijatelja“, nije do sada pronađena u izvornom obliku. No poznato je i u Sloveniji, Hrvatskoj, Bosni i Hercegovini, Srbiji i Crnoj Gori objelodanjeno niz dokumenata o uklanjaju grobalja i grobova „okupatora“ i "narodnih neprijatelja“ na području Slovenije, Hrvatske, Bosne i Hercegovine i Srbije u neposrednom poraću 1945. 1946. i 1947., utemeljenih na odluci MUP-a DF Jugoslavije od 18. maja 1945. o uklanjanju i uništavanju grobalja i grobova „okupatora“ i „narodnih neprijatelja“. ${ }^{2}$

Ministarstvo unutrašnjih poslova Narodne vlade Slovenije, Ljubljana, opširno je 12. juna 1945. izvijestilo okružne narodnooslobodilačke odbore u Sloveniji o odluci MUP-a DF Jugoslavije, Beograd, od 18. maja 1945., o uklanjanju grobalja i grobova „okupatora“ i „narodnih neprijatelja“. MUP Narodne vlade Slovenije, Ljubljana, u dopisu od 12. juna 1945. svim okružnim NOO-ima (Štev. 334/45, Predmet: Okupatorski grobovi), pojašnjava razloge uklanjanja grobalja i grobova „okupatora i domaćih izdajnika" nabrajajući mnogobrojne represivne postupke i zločine „okupatora i domaćih izdajnika" prema "našem narodu“ i "borcima“. Ministar unutrašnjih poslova Narodne vlade Slovenije Zoran Polič svim okružnim NOO-ima nalaže: „Naša zadaća je danas, da što prije zacijelimo teške rane prošlosti, da što prije odstranimo sve, što podsjeća na fašističku okupaciju u

${ }^{2}$ Usp. Vladimir Geiger, „Odluka o uklanjanju grobalja i grobova 'okupatora' i 'narodnih neprijatelja' Ministarstva unutarnjih poslova DF Jugoslavije od 18. svibnja 1945.", Politički zatvorenik, br. 257, (2014), 34-39; Isti, „Odluka o uklanjanju grobalja i grobova 'okupatora' i 'narodnih neprijatelja' Ministarstva unutarnjih poslova DF Jugoslavije od 18. svibnja 1945. (II.)”, Politički zatvorenik, br. 258, (2014), 29-34; Isti, „Odluka o uklanjanju grobalja i grobova 'okupatora' i 'narodnih neprijatelja' Ministarstva unutarnjih poslova DF Jugoslavije od 18. svibnja 1945. (III.)", Politički zatvorenik, br. 259, (2014), 12-17; Isti, „Nekoliko podataka o uklanjanju vojnih grobalja i grobova 'okupatora' i 'narodnih neprijatelja' u Bosni i Hercegovini nakon Drugoga svjetskog rata“, Politički zatvorenik, br. 262, (2015), 24-26; Isti, „Nekoliko podataka o uklanjanju vojnih grobalja i grobova 'okupatora' i 'narodnih neprijatelja' u Bosni i Hercegovini nakon Drugoga svjetskog rata (II.)", Politički zatvorenik, br. 263, (2015), 18-21; Isti, „O uklanjanju vojnih grobalja i grobova 'okupatora' i 'narodnih neprijatelja' u Sloveniji nakon Drugog svjetskog rata“, Politički zatvorenik, br. 264, (2015), 29-32; Isti, „O uklanjanju vojnih grobalja i grobova 'okupatora' i 'narodnih neprijatelja' u Sloveniji nakon Drugog svjetskog rata (II.)", Politički zatvorenik, br. 265, (2015), 3842; Isti, „Nekoliko podataka o uklanjanju vojnih grobalja i grobova 'okupatora' i 'narodnih neprijatelja' u Vojvodini nakon Drugog svjetskog rata“/„Einige Tatsachen über das entfernen von Militärfriedhöfen und Gräbern der 'Okkupatoren' und 'Staatsfeinde' in Wojwodina nach dem Zweiten Weltkrieg“, Fenster, br./Nr. 17, (2015), 12-15/16-19; Vladimir Geiger i Slađana Josipović Batorek, „O provođenju odluke komunističkih vlasti iz 1945. o uklanjanju grobalja i grobova 'okupatora' i 'narodnih neprijatelja' u Slavoniji i Srijemu“", Scrinia slavonica, sv. 15, (2015), 291-316. I ondje navedeni izvori i literatura. 
našoj zemlji i da prije svega što prije odstranimo tragove okupatorskih zločinaca i domaćih izdajnika. Zato je izdalo savezno ministarstvo za unutrašnje poslove 18. maja 1945. nalog po kojem moraju NOO-i učiniti sve potrebno, da se odmah odstrane /sravnaju sa zemljom/ sva groblja kao također i pojedini grobovi okupatora i domaćih izdajnika i tako izbriše svaki njihov trag. Partizanskim grobovima pak moraju posvetiti NOO-i svu potrebnu brigu i njegu, da istinski postanu spomenici zahvalnosti našim najvećim junacima. NOO-i moraju narodu pojasniti zašto moramo odstraniti grobove okupatora i domaćih izdajnika." Na kraju dopisa MUP-a Narodne vlade Slovenije, o uklanjanju grobalja i grobova „okupatora“ i „narodnih neprijatelja“, zatraženo je od svih okružnih NOO-a da ih obavijeste što su „učinili glede uklanjanja grobova i kakav odjek ima uklanjanje [grobova] u narodu. Smrt fašizmu - sloboda narodu! “3

Ministarstvo unutrašnjih poslova DF Jugoslavije dostavilo je u maju 1945. odluku o uklanjanju grobalja i grobova „okupatora“ i „narodnih neprijatelja“, prema svim pokazateljima, svim republičkim ministarstvima unutrašnjih poslova. Na obvezu provođenja odluke o uklanjanju grobalja i grobova „okupatora“ i „narodnih neprijatelja“ upućivao i upozoravao je MUP FNR Jugoslavije i kasnije sva republička ministarstva unutrašnjih poslova, pa i MUP NR Slovenije. ${ }^{4}$ Ministarstvo unutrašnjih poslova FNR Jugoslavije, Beograd, dopisom od 9. avgusta 1946. ukazalo je MUP-u NR Slovenije, Ljubljana, da je odlukom MUP-a DF Jugoslavije od 18. maja 1945. br. 1253, „odredjeno [je] da se groblja ili pojedine humke fašističkih okupatora uklone i sravne sa zemljom, tako da se zbriše svaki trag njihovog postojanja i uklone tragovi koji bi podsećali na mrskog okupatora" uz napomenu, da „Ukoliko ova naredba dosada nije provedena, potrebno je odmah provesti mere da se ona striktno provede i da se uklone svi tragovi fašističkih groblja ili pojedinih grobova." Zaključno pomoćnik ministra unutrašnjih poslova FNR Jugoslavije Petar Ivićević nalaže, da ih o izvršenju naredbe obavijeste. ${ }^{5}$

${ }^{3}$ Usp. Arhiv Republike Slovenije (ARS), Ljubljana, Republiški sekretariat za notranje zadeve SR Slovenije - Narodna vlada Slovenije Ministrstvo za notranje zadeve, Štev. 334/45, Dne. 12. junija 1945., Predmet Okupatorski grobovi, Vsem okrožnim NOO; Mitja Ferenc, Prikrito in očem zakrito. Prikrita grobišča 60 let po koncu druge svetovne vojne (Celje: Muzej novejše zgodovine, 2005), 25; Milko Mikola, Rdeče nasilje. Represija v Sloveniji po letu 1945 (Celje - Ljubljana: Mohorjeva družba, 2012), 61.

${ }^{4}$ Mitja Ferenc, „Zamločana grobišča Druge svetovne vojne v Sloveniji“, u: Totalitarizmi na Slovenskem $v$ 20. stoletju. Zbornik slovenskih prispevkov $z$ javne tribune $z$ naslovom Zločini totalitarnih režimov, ki je potekala 8. aprila 2008 v prostorih Evropske komisije v Bruslju, uredil Damjan Hančič (Ljubljana: Študijski center za narodno spravo, 2010), 146.

5 ARS, Ljubljana, Republiški sekretariat za notranje zadeve SR Slovenije Ministarstvo unutrašnjih poslova F. N.R. Jugoslavije, Str. Pov. br. 63, 9. VIII. 1946 god., Beograd, Predmet: Fašistički grobovi - poništaj, Ministarstvu unutrašnjih poslova Narodne 
Upute i naređenja o uklanjaju grobalja i grobova „okupatora“ i „narodnih neprijatelja“ redovito su prosljeđivana podređenim ustanovama na svim razinama, od najviših do najnižih organa vlasti. Ministarstvo unutrašnjih poslova Vlade NR Slovenije, Ljubljana, izvijestilo je 14. avgusta 1946. sve okružne i kotarske Odjele za unutrašnje poslove o dopisu MUP-a FNR Jugoslavije, Beograd, (Str. Pov. br. 63, od 9. VIII. 1946.), kojim se ponovno zahtijeva, i poziva na naredbu od 18.V.1945., br. 1253, „da se odmah odstrane - izravnaju sa zemljom sva groblja, kao i pojedini grobovi okupatora i domaćih izdajnika i tako izbriše svaki trag za njima, ako to nije već izvršeno." Pomoćnik ministra unutrašnjih poslova Vlade NR Slovenije, Boris Kocijančič, u dopisu napominje, da su „o učinjenom dužni izvjestiti.“ Napominje zatim, da je MUP Vlade NR Slovenije 12. juna 1945. izdao po tom pitanju svim okružnim NOO-ima okružnicu (štev. 334/45) „i pozvalo ih, da učine sve potrebno, da se odstrane takvi tragovi." No MUP Vlade NR Slovenije utvrđuje da se „u tom smjeru kod nas nije mnogo izvršilo“, naprotiv da rođaci „izdajnika“ ukrašavaju njihove grobove, iskazujući tako „izdajničku pripadnost“ i „reakcionarno mišljenje.“ Navode da je „stoga nužno, da se provođenju navedenih okružnica odmah i rigorozno pristupi“. Kako bi „uklanjanje navedenih grobova moglo prouzročiti u određenim krugovima, koji će pokušati pozivanjima na pietet i humanost prevariti narod i stvoriti neraspoloženje prema narodnoj vlasti, potrebno je, da se po tom pitanju stvar dobro politički pripravi“ te pojašnjavaju koje razloge uklanjanja grobova „okupatora i domaćih izdajnika“ treba prikazati narodu. „Zato se primite stvari odmah i energično i o svemu učinjenom nas izvijestite. Odmah nam pa izvijestite, kakvo je stanje sada, što je već učinjeno i koliko je još takvih grobalja odnosno pojedinih grobova na Vašem području. “6

U novinama, historiografiji i publicistici objavljeno je niz fotografija sahrana i grobalja i grobova „okupatora“ i "narodnih neprijatelja“ i u Sloveniji tijekom Drugoga svjetskog rata, koje potvrđuju onodobno stanje grobova i grobalja. ${ }^{7}$ Dokumenti i današnje stanje na grobljima potvrđuju da je

Republike Slovenije Ljubljana; Mitja Ferenc, Prekopi žrtev iz prikritih grobišč (1991.-2011) (Ljubljana: Znanstvena založba Filozofske fakultete, 2012), 8.

${ }^{6}$ ARS, Ljubljana, Republiški sekretariat za notranje zadeve SR Slovenije - Vlada Ljudske Republike Slovenije Ministrstvo za notranje zadeve, Kab. str. Pov. 626/46., V Ljubljani dne 14. avgusta 1946., Predmet: Odstranitev fašističnih grobov, Vsem okrožnim oddelkom in okrajnim odsekom za notranje zadeve; M. Ferenc, Prekopi žrtev iz prikritih grobišč (1991.-2011), 9.

${ }^{7}$ Usp. „Na Orlovem vrhu zadnjem počivališču slovenskih junakov. Slike s spominskih žalnih slovesnosti na praznik Vseh svetih leta 1944.“/„Gedenkfeier auf Orlov vrh. Der letzte Grabstätte slowenischer Helden Aufnahmen von don Feierlichkeiten am Allerheillgentag 1944 auf dem Ehrenfriedhof am Schloßberg", Slovensko domobranstvo, št. 8, (1944), 4-5; Jože Hubad, „Orlov vrh - simbol slovenstva“, Zaveza, št. 13, (1994), 59-61; Franc Benedik, „Nemško vojaško pokopališče v Kranju“, Kranjski zbornik 2000, (2000), 252-255; 
odluka MUP-a DF Jugoslavije o uklanjanju vojničkih grobalja okupatora u Sloveniji sustavno provođena.

Odsjek za unutrašnje poslove pri Kotarskom izvršnom odboru Rakek (Cerknica, Notranjska), izvijestio je 24. januara 1947. MUP NR Slovenije, Ljubljana, da su postupili po odluci MUP-a DF Jugoslavije, Beograd od 18. maja 1945. o uklanjanju vojničkih grobalja okupatora, uz napomenu, da je uklanjanje grobova izvela omladina uz pomoć drugih „masovnih organizacija“ te, da su u njihovom kraju „odstranili detaljno fašističke grobove“. U mjestima gdje uklanjanje vojničkih grobalja okupatora nije provedeno, bilo je to, navode, radi snijega. Izvijestiti će kada odstrane i te grobove. ${ }^{8}$

U Ljubljani su u neposrednom poraću 1945. na vojnom groblju na Orlovom vrhu uklonili nadgrobne oznake i otkopali grobove slovenskih domobrana (na iskopu su radili njemački ratni zarobljenici) te njihove posmrtne ostatke kamionima odvezli na nepoznatu lokaciju. ${ }^{9} \mathrm{Uz}$ to, na groblju Žale u Ljubljani preko noći „nestali“ su grobovi pravnika i političara dr. Marka Natlačena, teologa dr. Lamberta Erlicha (obojicu je po nalogu KP Slovenije 1942. ubila Sigurnosno-obavještajna služba Oslobodilačke fronte [Varnostno-obveščevalna služba Osvobodilne fronte]), a „nestali“ su i grobovi još nekih drugih istaknutih osoba, iako mrtvih, u poraću politički neprihvatljivih novim vlastodršcima. ${ }^{10}$

U neposrednom poraću 1945. ponegdje u Sloveniji nakon što su grobovi, najvjerojatnije, „nestručno“ raskopani nastaju higijenski problemi, kao u Crngrobu kod Pevnog (Škofja Loka), gdje su raskopani grobovi Hrvata, ustaša. Prema izvješću Mjesnog narodnog odbora Pevno od 29. decembra

Mitja Ferenc, Gojko Zupan i Mateja Bavdaž, Pokopališča in nadgrobniki kočevskih Nemcev/Friedhöfe und Grabsteine der Gottscheer Deutschen/Cemeteries and Tombstones of the Gottscheer Germans (Ljubljana: Zavod za varstvo kulturne dediščine Slovenije, 2002), 9-40; Mitja Ferenc, Kočevska pusta in prazna. Nemško jezikovno območje na Kočevskem po odselitvi Nemcev (Ljubljana: Modrijan, 2005), 185, 377, 637-644; Idem, Prikrito in očem zakrito, 33; Idem, Prekopi žrtev iz prikritih grobišč (1991.-2011), 8; V. Geiger, „O uklanjanju vojnih grobalja i grobova 'okupatora' i 'narodnih neprijatelja' u Sloveniji nakon Drugog svjetskog rata (II.)“, 39-42.

${ }^{8}$ ARS, Ljubljana, Republiški sekretariat za notranje zadeve SR Slovenije - Narodna vlada Slovenije Ministrstvo za notranje zadeve, Odsek za notranje zadeve pri OIO v Rakeku - Rakek, Dne 24. januarja 1947., Štev. Kab. 54/1, Predmet: Odstanitev fašističnih grobov, Ministrstvu za notranje zadeve v Ljubljani; M. Ferenc, Prikrito in očem zakrito, 25; Idem, Prekopi žrtev iz prikritih grobišč (1991.-2011), 9.

${ }^{9}$ Franc Perme, „Zamolčani grobovi in njihove žrtve“, u: Slovenija. Zamolčani grobovi in njihove žrtve 1941-1948. Zbornik, uredniški odbor Franc Perme, Anton Žitnik i Davorin Žitnik (Ljubljana - Grosuplje: Društvo za ureditev zamolčanih grobov, 1998), 69; M. Ferenc, Prekopi žrtev iz prikritih grobišč (1991.-2011), 8.

${ }^{10}$ France Martin Dolinar, „Duhovniki v primežu revolucije“, u Žrtve vojne in revolucije. Zbornik, uredniški odbor Janvit Golob, Peter Vodopivec, Janko Prunk i Milena Basta (Ljubljana: Državni svet Republike Slovenije, 2005), 66; M. Ferenc, Prekopi žrtev iz prikritih grobišč (1991.-2011), 8. 
1945. Odjelu za unutrašnje poslove Okruga Škofja Loka, „to uzrokuje neprijatan miris i onečišćuje zrak, zato je opasno da se ne proširi kakva bolest."11

No u Jugoslaviji, pa i Sloveniji, odnos prema sjećanju na mrtve „neprijatelje“ nije uvijek bio isti, i ovisio je od mjesnih prilika odnosno o revnosti mjesnih pojedinaca i vlasti. U mjestu Rovte kod Logatca podignuta je u avgustu 1944. spomen-kapelica (Marijina kapelica) župljanima poginulim u Prvom svjetskom ratu i tijekom Drugog svjetskog rata te su imena poginulih do početka studenoga 1944. upisana na spomen-pločama, a među kojima je bilo i poginulih slovenskih domobrana, pripadnika seoskih straža, a i partizana, kao i mještana civila koje su ubili Talijani, Nijemci i partizani. ${ }^{12}$ U poraću 1945. odluku MUP-a DF Jugoslavije od 18. maja 1945. odnosno odluku MUP-a Narodne vlade Slovenije od 12. juna 1945. proslijedio je Okružni narodni odbor Logatec u Rovte s nalogom uklanjanja spomenkapelice i spomen-ploča. No do uklanjanja stjecajem okolnosti, ipak, nije došlo, a 1993. u spomen-kapelicu dodane su spomen-ploče s imenima župljana poginulih ili ubijenih od početka novembra 1944. do završetka Drugoga svjetskog rata i imena ubijenih u neposrednom poraću $1945 .{ }^{13}$

Uklanjanje grobalja i grobova „okupatora“ i "narodnih neprijatelja“ nije bilo bez poteškoća za vlast, na različitim razinama. Povjerenik za narodnu obranu okruga Ljutomer u dopisu od 12. jula 1951. pomoćniku ministra za unutrašnje poslove NR Slovenije, Peteru Zorku, napominje kako su ustanovili, da „svi ljudi tamo gdje se nalaze grobovi [„neprijatelja“], pamte podatke [o njihovim lokacijama], tako da bi bilo uklanjanje nadgrobnih oznaka ili grobova riskirana stvar." ${ }^{14}$ Uklanjanje grobova i grobalja „okupatora" i "narodnih neprijatelja" nije moglo biti nezamijećeno, a i bez odjeka u najširim masama stanovništva. U skladu s tim vlast je, uza svu samovolju u represivnom ozračju, nastojala prikazati svoju odluku opravdanom i pravičnom. Ministarstvo unutrašnjih poslova Narodne vlade Slovenije 12. juna 1945. pojašnjava kao razlog uklanjanja grobalja i grobova neprijateljskih

${ }^{11}$ Zgodovinski arhiv Ljubljana, Enota Škofja Loka, Krajevni ljudski odbor Pevno, Tehničkna enota 1, - Krajevni narodni odbor Pevno, Pevno, dne 29. 12. 1945., štev. 348/45, Oddelku za notranje zadeve Okraja Škofja - Loka; Mitja Ferenc i Želimir Kužatko, Prikrivena grobišta Hrvata u Republici Sloveniji/Prikrita grobišča Hrvatov v Republiki Sloveniji/Hidden Croatian Mass Graves in the Republic of Slovenia (Zagreb: Počasni bleiburški vod, 2007), 85, 88-89.

${ }^{12}$ Usp. „Odkritje spomenika padlim v Rovtah“/,Eröffnung einer Heldengedenkstätte in Rovte“, Slovensko domobranstvo, št. 8, (1944), 6; Janko Maček, „Ob 70-letnici spominske kapelice prve in druge svetovne vojne ter revolucije v Rovtah“, Zaveza, št. 94, (2014), 13-22.

13 J. Maček, „Ob 70-letnici spominske kapelice prve in druge svetovne vojne ter revolucije v Rovtah", 14.

${ }^{14}$ ARS, Ljubljana, III, Republiški sekretariat za notranje zadeve SR Slovenije, f. 63, Komunalne zadeve, prekopi 1945-1970, m. 31, dopis povjerenika za okraj Ljutomer pomoćniku ministra za notranje zadeve LR Slovenije, 12. 7. 1951; M. Ferenc, Prekopi žrtev iz prikritih grobišč (1991.-2011), 8, 24. 
vojnika: „Okupator je svoj pokušaj podjarmljivanja i istrebljenja našeg naroda platio s velikim brojem mrtvih. Svoje mrtve je prenosio u mjesta, /središta svojih vojnih baza/ i tamo ih sahranjivao sa velikim počastima uz sudjelovanje domaćih izdajnika. Tako su u blizini svih naših mjesta nastala brojna brižno uređena groblja okupatora. Na hiljade i hiljade naših boraca, koji su pali za našu slobodu pa leži širom naše zemlje po šumama, livadama i jarcima, bez bilo kakvog humka, bez bilo kakvog natpisa. Okupator je svaki partizanski grob koji je našao uništio. " ${ }^{15}$ Ministarstvo unutrašnjih poslova Vlade NR Slovenije 14. avgusta 1946. pojašnjava slično: „Narodu je potrebno prikazati, kako su okupator i domaći izdajnici prenosili svoje žrtve u mjesta i veće vojne baze i tamo ih pokopavali sa velikim počastima, dok leže hiljade boraca, koji su pali za slobodu, razbacani po šumama, livadama i jarcima bez bilo kakvog znamenja i bez bilo kakvog natpisa, da su strijeljani taoci pobacani u zajedničke jame, za koje se ne zna, gdje su i da je bilo na hiljade interniraca zapaljenih u tuđini u krematorijima i njihov pepeo razbacan po njivama kao gnojivo. Obitelji tih junaka uzalud traže njihove grobove, da bi ih posjećivali i ukrašavali. Pred očima tih pogođenih obitelji kočopere se grobovi izdajnika, koji ih neprestano podsjećaju na ubojice njihovih sinova, braće, sestara i roditelja i na drugoj strani zasjenjuju polet našega naroda, koji hoće obračunati sa svim starim i izgraditi novo." 16

Dokumenti potvrđuju da su republička pojašnjenja o razlozima uklanjanja grobalja i grobova „okupatora“ i "narodnih neprijatelja“ bila ujednačena i očito su bila izvorno dio odluke MUP-a DF Jugoslavije, br. 1253, od 18. maja 1945. Na provođenje odluke MUP-a DF Jugoslavije od 18. maja 1945. o uklanjanju i uništavanju grobalja i grobova „okupatora“ i "narodnih neprijatelja“ narod je u ozračju straha negodovao, potvrđuju i dokumenti i sjećanja suvremenika događaja. Odsjek za unutrašnje poslove pri Kotarskom izvršnom odboru Rakek (Cerknica), u izvještaju od 24. januara 1947. MUP-u NR Slovenije, Ljubljana, da su postupili po odluci [MUP-a DF Jugoslavije, Beograd od 18. maja 1945.] o uklanjanju vojničkih grobalja okupatora, napominje: „Narod koji je bio usmjeren za naš pokret, bio je zadovoljan, ostalo stanovništvo odnosno simpatizeri be-ga [Bela garda], bili

${ }^{15}$ Usp. ARS, Ljubljana, Republiški sekretariat za notranje zadeve SR Slovenije Narodna vlada Slovenije Ministrstvo za notranje zadeve, Štev. 334/45, Dne. 12. junija 1945., Predmet Okupatorski grobovi, Vsem okrožnim NOO; M. Ferenc, Prikrito in očem zakrito, 25; M. Mikola, op. cit., 61.

${ }^{16}$ ARS, Ljubljana, Republiški sekretariat za notranje zadeve SR Slovenije - Vlada Ljudske Republike Slovenije Ministrstvo za notranje zadeve, Kab. str. Pov. 626/46., V Ljubljani dne 14. avgusta 1946., Predmet: Odstranitev fašističnih grobov, Vsem okrožnim oddelkom in okrajnim odsekom za notranje zadeve; M. Ferenc, Prekopi žrtev iz prikritih grobǐ̌c (1991.-2011), 9. 
su ogorčeni i nezadovoljni. No da bi stvarali kakve zaprjeke pri izvršavanju toga nije se moglo zapaziti." ${ }^{17}$

Katolička crkva iskazivala je u neposrednom poraću 1945. otvoreno protivljenje uništavanju grobova poginulih „neprijateljskih" vojnika u Jugoslaviji od strane "narodnih" vlasti. ${ }^{18}$ Najznačajnije i najpoznatije je Pastirsko pismo katoličkih biskupa Jugoslavije, izdano 20. septembra 1945. na općim biskupskim konferencijama u Zagrebu, o položaju Katoličke crkve u Jugoslavije u neposrednom poraću i odnosu novih jugoslavenskih vlasti prema Katoličkoj crkvi i vjernicima. Pismo ukazuje i na uklanjanje grobova od strane vlasti i napominje: „[...] Ovakav postupak mora se osuditi. Pred smrću klanjaju se svi ljudi. I neprijatelj prestaje poslije smrti biti neprijatelj. I njemu pripada po nepisanim zakonima čovječanske uljudbe, koja izvire iz kršćanske ljubavi, pravo na pristojan grob. Poznato je, da su poslije prvoga svjetskog rata nekadanji neprijatelji i te kako poštivali i čuvali grobove vojnika, koji su kao osvajači pali u stranim zemljama. Danas se to kod nas uskraćuje vlastitim sinovima“. ${ }^{19}$ Zatim je i 22. septembra 1945., završnoga dana zasjedanja na općim biskupskim konferencijama u Zagrebu, upućena i predstavka katoličkih biskupa Jugoslavije maršalu Josipu Brozu Titu u svezi s crkveno-državnim odnosima koja, među ostalim, ukazuje i na uništavanje grobova vojnika od strane vlasti. ${ }^{20}$

Ogledni primjer stajališta komunističkih vlasti i Katoličke crkve u Jugoslaviji o odnosu prema grobovima „okupatora“ i „narodnih neprijatelja“ jeste razgovor ministra unutrašnjih poslova NR Slovenije Zorana Poliča i generalnog vikara ljubljanske biskupije Antona Vovka, 31. septembra 1945. Sutradan nakon čitanja Pastirskoga pisma u slovenskim crkvama,

${ }^{17}$ ARS, Ljubljana, Republiški sekretariat za notranje zadeve SR Slovenije - Narodna vlada Slovenije Ministrstvo za notranje zadeve, Odsek za notranje zadeve pri OIO v Rakeku - Rakek, Dne 24. januarja 1947., Štev. Kab. 54/1, Predmet: Odstanitev fašističnih grobov, Ministrstvu za notranje zadeve v Ljubljani; M. Ferenc, Prikrito in očem zakrito, 25; Idem, Prekopi žrtev iz prikritih grobǐ̌č (1991.-2011), 9; M. Mikola, op. cit., 63.

${ }^{18}$ Usp. Vladimir Geiger, „Odluka o uklanjanju grobalja i grobova 'okupatora' i 'narodnih neprijatelja' Ministarstva unutarnjih poslova DF Jugoslavije od 18. svibnja 1945. i Katolička crkva u Jugoslaviji“, Tkalčić, br. 18, (2014), 387-426. I ondje navedeni izvori i literatura.

19 Arhiv Hrvatske biskupske konferencije (Arhiv HBK), Zagreb - spisi 1945., br. 114 BK/1945., Pastirsko pismo katoličkih biskupa Jugoslavije, izdano s općih Biskupskih konferencija u Zagrebu, dne 20. rujna 1945; V. Geiger, „Odluka o uklanjanju grobalja i grobova 'okupatora' i 'narodnih neprijatelja' Ministarstva unutarnjih poslova DF Jugoslavije od 18. svibnja 1945. i Katolička crkva u Jugoslaviji“, 398, 413-414. I ondje navedena literatura.

20 Arhiv HBK, Zagreb - spisi 1945., br. 107 BK/1945. - Predstavka nadbiskupa Alojzija Stepinca i katoličkih biskupa Jugoslavije Josipu Brozu Titu u svezi s crkvenodržavnim odnosima, 22. rujna 1945; V. Geiger, „Odluka o uklanjanju grobalja i grobova 'okupatora' i 'narodnih neprijatelja' Ministarstva unutarnjih poslova DF Jugoslavije od 18. svibnja 1945. i Katolička crkva u Jugoslaviji“, 399-340, 416-417. I ondje navedena literatura. 
ministar Polič pozvao je na razgovor generalnog vikara Vovka i, među ostalim, prigovorio mu je da se [Katolička crkva] „zauzima za grobove njemačkih vojnika, ustaša i domobrana“ te napomenuo da je njegova „etika drukčija“. Uz to ministar Polič prigovorio je, „zašto se samo danas crkvene vlasti zauzimaju za grobove“. Generalni vikar Vovk je, pak, odgovorio da su „u smrti svi jednaki“ i naveo da "to što se događa sa grobovima kod nas [u Sloveniji], događa se i drugdje [u Jugoslaviji].” Vovk je naglasio i da je „po pitanju grobova [Katolička] crkva imala uvijek isti odnos poštovanja."

U Sloveniji, kao i drugdje u Jugoslaviji, žrtve „neprijatelja“ sustavno su brisane iz javnog sjećanja i uskraćivalo im se pravo na grob. Masovne grobnice, pojedinačni grobovi i žrtve „neprijatelja“ jednostavno nisu smjele postojati. Groblja i grobovi „neprijatelja“ u Sloveniji bili su razoreni, uništeni i prikriveni. Na mjestima gdje su se takva groblja i grobovi nalazili često su građene stambene $\mathrm{i}(\mathrm{li})$ poslovne zgrade, parkirališta, ceste ili, primjerice, gradske deponije. ${ }^{22}$

Uništavana su ili krajnjem nemaru i propadanju prepuštena groblja i grobovi uz nekadašnja njemačka (folksdojčerska) naselja u Jugoslaviji. Najslikovitiji i ogledni primjer odnosa prema grobljima uz njemačka naselja u Jugoslaviji područje je Kočevja u Sloveniji, gdje groblja nisu samo prepuštena nemaru i propadanju, nego su i planski i sustavno uklanjana. ${ }^{23}$

Ženevske konvencije (o postupanju s ratnim zarobljenicima) iz 1929. normirale su međunarodno ratno, humanitarno i kazneno pravo. Ove konvencije su propisale i „da ratni zarobljenici koji umru u zarobljeništvu budu časno sahranjeni i da na grobovima budu označeni svi korisni podaci, da grobovi budu poštovani i pristojno održavani." Uz to strana u ratnom sukobu kojoj su pripadali umrli zarobljenici mora biti obaviještena o svim slučajevima smrti i sahranjivanja, kao i o lokacijama njihovih grobova. ${ }^{24}$ No

21 Nadškofijski arhiv v Ljubljana, Zapuščina škofa Antona Vovka - Razgovor z ministrom za notranje zadeve LR Slovenije Zoranom Poličem, 31. septembra 1945; Anton Vovk, V spomin in opomin. Osebni zapisi škofa Antona Vovka od 1945 do 1953, uredil Blaž Otrin (Ljubljana: Družina, 2008), 257, 259-260; V. Geiger, „Odluka o uklanjanju grobalja i grobova 'okupatora' i 'narodnih neprijatelja' Ministarstva unutarnjih poslova DF Jugoslavije od 18. svibnja 1945. i Katolička crkva u Jugoslaviji“, 401, 418-419.

${ }_{22}$ Usp. M. Ferenc, Prikrito in očem zakrito, 24-26, 78-81; Idem, „Taborišče Teharje in prikrita grobišča v Sloveniji“, u: Iz zgodovine Celja 1941-1945, glavna urednica Marija Počivavšek (Celje: Muzej novejše zgodovine, 2004), 219-226; Janez Črnej, Grobišča na Štajerskem (Ljubljana: Samozaložba, 2009), 60-68, 91-100.

${ }^{23}$ Usp. M. Ferenc, G. Zupan i M. Bavdaž, op. cit., 9-40; M. Ferenc, Kočevska pusta in prazna, 185, 377, 637-644.

${ }^{24}$ Usp. primjerice: Boško Petković, Međunarodne konvencije o ratnom pravu (Zagreb: Sveučilišna tiskara d.o.o., 1992), 151; Jelena Đ. Lopičić-Jančić, Krivičnopravna zaštita ratnih zarobljenika u jugoslovenskom krivičnom pravu (Beograd: IP „Vaša knjiga“ d.o.o., 2005), 152; Zoran Vučinić, Međunarodno ratno i humanitarno pravo (Beograd: Službeni glasnik, 2006), 274. 
Jugoslavija se nije pridržavala odredaba Konvencije o postupanju sa ratnim zarobljenicima i grobovi i groblja ratnih zarobljenika su uništavana ili prepuštena propadanju. U poraću su vlasti u Sloveniji, očito je, vodile točnu evidenciju o lokacijama grobalja i grobova „okupatora“ i „narodnih neprijatelja" i onih koja su uklonjena i onih prepuštenih nemaru i propadanju. Ogledni primjer jeste popis 120 lokacija pojedinačnih i skupnih grobova „neprijateljskih" vojnika na području općine Ilirska Bistrica naslovljen Popis grobova neprijateljevih vojnika palih u vrijeme NOR-a na području općine Ilirska Bistrica [Seznam grobov sovražnikovih vojakov padlih v času NOV. na območju občine Ilirska Bistrica], nastao najvjerojatnije početkom 1960-ih godina, i očito na temelju ranijih zabilješki i popisa i najvjerojatnije za potrebe MUP-a za nadzor nad grobištima. ${ }^{25}$

Nakon Drugoga svjetskog rata u Jugoslaviji grobovi i groblja poginulih partizana i grobovi i groblja žrtava "fašističkog terora" zakonima su bili zaštićeni, uređivani i održavani, a grobovi i groblja „neprijateljskih“ vojnika i grobovi "suradnika okupatora“ ostali su izvan zakona. I tako je bilo sve do raspada SFR Jugoslavije. Oni, pak, koji su zastupali stajalište da svatko ima pravo na grob i sjećanje imali su znatnih neugodnosti, štoviše bili su sudski progonjeni. Poseban nadzor i brigu vodio je o takvim pojavama, među ostalima nadležnim organima, očito, i Savez udruženja boraca narodnooslobodilačkog rata. Okružni odbor SUBNOR-a Nova Gorica, izvijestio je u novembru 1957. sve općinske odbore SUBNOR-a i sve općinske narodne odbore o „neprimjernim“ natpisima na nadgrobnim spomenicima na seoskim grobljima, navodeći da su rođaci nekih likvidiranih „izdajnika i pripadnika Bele Garde" upisali neprimjerne natpise na nadgrobne spomenike. Kako smatraju, da natpisi na grobovima navedenih („Naše roke nisu umazane od krvi“ [„Naše ruke nisu umazane krvlju“], „Padel kot nedolžna žrtev“ [„Pao kao nedužna žrtva“], „Za boga in dom je padel“ [„Za Boga i za Dom je poginuo“]) „blate našu narodnu revoluciju“ mišljenja su, da „naša narodna vlast mora učiniti sve potrebno, da se ovi natpisi što prije odstrane." Uz to nalažu da općinski NO-i pregledaju spomenike i spomen-ploče na grobljima, gdje ima vjerojatno još takvih primjera. Također preporučuju da rođake navedenih (likvidiranih „izdajnika i pripadnika Bele Garde“) pozovu na razgovor i daju im upute, da sami odstrane inkriminirajuće natpise. Napominju da ako na odstranjenje natpisa pojedinci ne bi pristali, mora Općinski NO izdati odluku o odstranjenju takvog natpisa. ${ }^{26}$

${ }^{25}$ Usp. Mitja Ferenc, ,'... Grobovi so zravnani in zaraščeni' (Seznam grobov sovražnikovih vojakov padlih iz časa 2 . svetovne vojne na območju občine Ilirska Bistrica)", Prispevki za novejšo zgodovino, št. 1, (2004), 164-168.

${ }^{26}$ Pokrajinski arhiv v Novi Gorici (PA NG), Komisija za raziskavo povojnih množičnih pobojev, pravno dvomljivih procesov in drugih nepravilnosti Občine Vipava - Okrajni 
Zabrana prijenosa posmrtnih ostataka „narodnih neprijatelja“ $u$ obiteljske grobnice na zavičajnim grobljima bila je uobičajena. Odsjek za unutrašnje poslove Povjereništva Pokrajinskoga NOO-a za Slovensko Primorje, Ajdovščina, dostavio je 11. decembra 1945. okružnim NOO-ima, okružnim zapovjedništvima Narodne zaštite, Zapovjedništvu Narodne zaštite pri Pokrajinskom NOO-u dopis naslovljen „Iskop i prijenos posmrtnih ostataka izdajnika i protivnika narodno-oslobodilačkog pokreta" u kojemu navode da se događa „da rođaci pojedinih osoba, koje su bile zbog svojega djelovanja protiv narodno-oslobodilačkog pokreta i suradnje sa okupatorom, likvidirane tijekom narodno-oslobodilačke borbe, njihove posmrtne ostatke iskopavaju i prenose radi sahrane na mjesnim grobljima. U takvim slučajevima priređuju sahrane više ili manje svečano i nastoje slučaju dati politički značaj te prikazati pokojnoga kao nedužnu žrtvu, što je reakciji dobrodošao povod za djelovanje protiv narodne vlasti i osvobodilne fronte." Naglašavaju, da „narodna vlast prema takvim pojavama ne može biti indiferentna i bezbrižna" te da je „Izdajnike i neprijatelje naroda zadesila pravična kazna, koju im je izrekao cjelokupan narod. Nije im bila izrečena samo kazna smrti, nego ujedno i kazna gubitka narodne časti te iz toga slijedi, da im je oduzeta također svaka posmrtna čast." Zaključno načelnik Odsjeka za unutrašnje poslove Pokrajinskog NOO-a za Slovensko primorje Albin Čotar nalaže „da moraju grobovi izdajnika biti zaboravljeni i da se mora izbrisati njihov svaki trag i sjećanje te da se na taj način sačuva narodna čast na dostojnoj visini neokrnjena."27 Okružni izvršni NOO za Vipavsko, Ajdovščina, prosljedio je 15. decembra 1945. okružnicu Odsjeka za unutrašnje poslove Povjereništva Pokrajinskoga NOO-a za Slovensko primorje, Ajdovščina, „Iskop i prijenos posmrtnih ostataka izdajnika i protivnika narodnooslobodilačkog pokreta" svim NOO-ima na Vipavskem, uz napomenu „Molimo, da se uputa strogo držite. “28

odbor ZB NOV Gorica, štev. 539/57, Dne. 9. XI. 1957., Vsem občinskim odborom Zveze borcev in vsem občinskim ljudskim odborom v vednost. Zadeva: Neprimerni napisi na nadgrobnih spomenikih; Renato Podberšič, Revolucionarno nasilje na Primorskem. Goriška in Vipavska 1941-1945 (Ljubljana: Študijski center za narodno spravo, 2011), 119.

${ }^{27}$ PA NG, Komisija za raziskavo povojnih množičnih pobojev, pravno dvomljivih procesov in drugih nepravilnosti Občine Vipava - Povjereništvo Pokrajinskega NOO za Slovensko Primorje odsek za notranje zadeve, Štev. 957/45, Ajdovščina, dne 11.12.1945., Predmet: Izkop in prenos posmrtnih ostankov izdajalcev in nasprotnikov narodno osvobodilnega pokreta, Okrajnim NO odborom, Okrajnim poveljstvom NZ, Poveljstvu NZ pri PNOO; R. Podberšič, op. cit., 135.

28 Usp. PA NG, Krajevni ljudski odbor Vrhpolje, leto 1945-1946, fasc. 1 Povjereništvo Pokrajinskega NOO za Slovensko Primorje odsek za notranje zadeve, Štev. 957/45, Predmet: Izkop in prenos posmrtnih ostankov izdajalcev in nasprotnikov narodno osvobodilnega pokreta, - Okrajni I. N.O. O za Vipavsko Ajdovščina 15/12/45, Tek. št. 1732/45/12, Vsem krajevnem NOO na Vipavskem okraju; Pavel Jamnik, „Zavedanje zločina. 
U Sloveniji su tijekom Drugoga svjetskog rata, gdje i kada je to bilo moguće, poginule vojnike u borbama s partizanima i one koje su ubili partizani prenosili rođaci i sumještani iz pojedinačnih i skupnih grobova, na mjestima pogibije, i sahranjivali ih u skupne ili obiteljske grobnice na mjesnim grobljima. U poraću takvi su prijenosi posmrtnih ostataka u pravilu pojedinaca bili rijetki i obavljani su u tajnosti. Posmrtne ostatke obitelj je prenosila i sahranjivala u obiteljskoj grobnici ili negdje na mjesnom groblju, ili uz groblje, ponekad bez nazočnosti svećenika. ${ }^{29} \mathrm{U}$ martu 1944. partizani su ubili Jožu Okorna iz Škofje Loke. U neposrednom poraću obitelj Okorn je saznala gdje je grob J. Okorna, i njegova kćerka Marija zamolila je nadležne vlasti da joj omoguće prenijeti očeve posmrtne ostatke na mjesno škofjeloško groblje. Kako dopuštenje nije dobila, obitelj Okorn uputila se 1. maja 1946. na „izlet“ i potajno iskopala kosti i u tri nahrptnjače donijela ih kući. Kako su bili u strahu, da bi sahranu na mjesnom groblju netko mogao opaziti, očeve kosti sahranili su u vrtu, gdje se nalaze i danas. Da bi priča bila slikovitija, škofjeloški Okružni sud je u međuvremenu zaključio da je Jože Okorn likvidiran „zabunom“. ${ }^{30}$

Uništavanja vojničkih grobova „neprijatelja“ bilo je u SFR Jugoslaviji ne samo u neposrednom poraću nego i znatno kasnije. U Sloveniji je sve do potkraj 1980-ih godina Služba državne sigurnosti u blizini neobilježenih grobišta, ponajprije onih koja su bila poznatija, pratila tko dolazi na mjesta gdje su bili posmrtni ostaci tijekom Drugoga svjetskog rata i u neposrednom poraću ubijenih „neprijatelja“, vojnika i civila. ${ }^{31}$ Kada su u Sloveniji početkom 1950-ih godina iz pojedinačnih i udaljenijih grobova prenosili $u$ skupne grobnice poginulih boraca, u većem broju posmrtne ostatke poginulih partizana, vlast je bila posebno pozorna, da ne dođe do zloraba i prijenosa posmrtnih ostataka „neprijatelja“. Naime pomoćnik ministra za unutrašnje poslove NR Slovenije, Peter Zorko, u okružnici od 8. januara 1953., naslovljenoj Provođenje propisa o prijenosu mrtvih [Izvajanje predpisov o prevozih mrličev], naglašava da „organi za unutrašnje poslove posebno skrbe, da organi NO-a ne izdaju dozvole za iskope i prijenos posmrtnih ostataka neprijatelja NOB, kao npr. poginulih belogardejaca, narodnih izdajnika i

Začetki policijskega in tožilskega preiskovanja nezastarljivih zločinov, storjenih po koncu 2. svetovne vojne v Sloveniji“, u: Totalitarizmi - vprašanja in izzivi. Ob dvajsetletnici padca železne zavese $v$ Evropi. Zbornik prispevkov z mednarodnega posveta 9. novembra 2009. v Ljubljani, uredila Mateja Čoh (Ljubljana: Študijski center za narodno spravo, 2009), 95-96.

${ }^{29}$ Usp. M. Ferenc, Prekopi žrtev iz prikritih grobišč (1991.-2011), 7.

${ }^{30}$ Usp. Janko Maček, „Revolucija jim je zadala neozdravljive rane“, Zaveza, št. 79, (2010), 16-24; M. Ferenc, Prekopi žrtev iz prikritih grobišč (1991.-2011), 7-8.

${ }^{31}$ Usp. M. Ferenc, ,'... Grobovi so zravnani in zaraščeni' (Seznam grobov sovražnikovih vojakov padlih iz časa 2. svetovne vojne na območju občine Ilirska Bistrica)“, 162; Idem, Prikrito in očem zakrito, 24; Idem, Prekopi žrtev iz prikritih grobišč (1991.-2011), 8. 
drugih, koji su u vrijeme rata djelovali protiv narodno-oslobodilačkog pokreta." Okružnica napominje i kako treba sve provjeravati u grobljanskim knjigama, sa grobarom i drugima te paziti, „da ne bude zloraba, da se ne bi npr. iskopao i prenio belogardejac sa dozvolom koja glasi na drugo ime.“32

Republički zakoni o pogrebnoj djelatnosti i o uređivanju grobalja ili, pak, zakoni o prekršajima protiv javnog reda i mira, doneseni tijekom 1970ih i 1980-ih godina i koji su bili na snazi sve do raspada SFR Jugoslavije $u$ pravilu nisu dozvoljavali na grobljima postavljanje oznaka, natpisa, slika i simbola, koji označavaju pripadnost umrlih neprijateljskom pokretu, usmjerenom protiv Narodnooslobodilačke vojske Jugoslavije odnosno njihovu neprijateljsku djelatnost protiv društvenog uređenja SFR Jugoslavije. U Sloveniji je Zakon o grobljanskoj i pogrebnoj djelatnosti te o uređenju grobalja [Zakon o pokopališki in pogrebni dejavnosti ter o urejanju pokopališč] iz 1984. propisivao člankom 35.: „Na grobljima nije dozvoljeno postavljanje oznaka, natpisa, slika i simbola, koji označavaju pripadnost umrlih neprijateljskom pokretu, usmjerenom protiv NOB Jugoslavije odnosno njihovu neprijateljsku djelatnost protiv društvenog uređenje SFRJ." Zakon o grobljanskoj i pogrebnog djelatnosti te o uređenju grobalja SR Slovenije, određivao je, člankom 36., da „ako upravitelj groblja ustanovi, da se na groblju izvode radnje u suprotnosti s [...] i 35. člankom ovog zakona, mora o tome obavijestiti za komunalne poslove nadležni općinski upravni organ" te je propisivao i kaznene odredbe, i za komunalne organizacije, člankom 41.: „Novčanom kaznom od 20.000 do 50.000 dinara kazniti će se za prekršaj komunalne organizacije: [...] - ako ne obvijesti za komunalne poslove nadležnoga općinskog upravnog organa o kršenju odredbi 35. člana ovog zakona. Novčanom kaznom od 1.000 do 5.000 dinara kazniti će se za prekršaj odgovorna osoba komunalne organizacije, koja učini radnje iz prethodnoga stavka." Zatim navodi i kaznenu odredbu za građane, člankom 42.: "[...] Novčanom kaznom od 3.000 do 10.000 dinara kazniti će se za prekršaj građanin, ako izvede radnje ili naruči izvođenje radnji u suprotnosti s 35. članom ovog zakona." ${ }^{33}$

Odluka MUP-a DF Jugoslavije od 18. maja 1945. odnosno odluka MUP-a NR Slovenije od 12. juna 1945., o uklanjanju i uništavanju grobalja i grobova "okupatora" $\mathrm{i}$ „narodnih neprijatelja" u pravilu je sustavno provođena, kao i sve kasnije odluke i zakonski propisi o grobovima "okupatora" i "narodnih neprijatelja“. Redovito je to bilo uvjetovano smještajem/mjestom pojedinog groblja ili groba na koje se je navedena odluka trebala odnositi, ali i svjetonazorom i revnošću onih koji su odluku trebali provoditi.

${ }^{32}$ ARS, Ljubljana, III, Republiški sekretariat za notranje zadeve SR Slovenije, f. 63, - Komunalne zadeve, prekopi 1945-1970, m. 36, Izvajanje predpisov o prevozih mrličev, 8. 1. 1953.; M. Ferenc, Prekopi žrtev iz prikritih grobišč (1991.-2011), 8, 24.

33 „Zakon o pokopališki in pogrebni dejavnosti“, Uradni list Socijalistične Republike Slovenije, št. 34, 19. XI. 1984, 1875-1879. 
U Sloveniji „nesmetano“ odnosno nekažnjivo označavanje i ispisivanje imena na nadgrobnim spomenicima obiteljskih grobnica ili pojedinačnih kenotafa onih članova obitelji koji su život izgubili tijekom Drugoga svjetskog rata i u poraću kao pripadnici Wehrmachta, Slovenskog domobranstva, Jugoslovenske vojske u Otadžbini i drugih „neprijateljskih vojska“ ili koji su, pak, likvidirani kao „narodni neprijatelji“ - postalo je moguće tek nakon raspada SFR Jugoslavije. U Sloveniji posebno mjesto u obilježavanju imena i vojnika i civila koji su tijekom Drugoga svjetskog rata i u poraću „umrli nasilnom smrću na protukomunističkoj strani“ imaju Farne spominske plošče (Župske spomen-ploče). Mnogobrojne kamene spomen-ploče sa uklesanim imenima mještana koji ranije većinom nisu imali nikakva obilježja postavljene su najčešće uz pročelja mjesnih crkava ili na grobljima. ${ }^{34}$

Znakovito je, u Sloveniji na nekim mjesnim grobljima obnovljena su njemačka vojna groblja iz Drugoga svjetskog rata i postavljena spomenobilježja s imenima poginulih vojnika, ${ }^{35}$ ali vojna groblja Slovenskog domobranstva nisu obnovljena. Štoviše tome postoje znatni otpori i protivljenja lijevo usmjerenih, „antifašističkih“, skupina i pojedinaca, kao što nisu obnovljena ni vojna groblja nacionalnih protukomunističkih snaga u Hrvatskoj, Bosni i Hercegovini, Srbiji, Crnoj Gori i Makedoniji, državama nastalim raspadom SFR Jugoslavije.

\section{IZVORI I LITERATURA}

- Arhiv Hrvatske biskupske konferencije, Zagreb - spisi 1945.

- Arhiv Republike Slovenije, Ljubljana - Republiški sekretariat za notranje zadeve SR Slovenije

- Nadškofijski arhiv v Ljubljana - Zapuščina škofa Antona Vovka

- Pokrajinski arhiv v Novi Gorici - Komisija za raziskavo povojnih množičnih pobojev, pravno dvomljivih procesov in drugih nepravilnosti Občine Vipava; Krajevni ljudski odbor Vrhpolje

- Zgodovinski arhiv Ljubljana, Enota Škofja Loka - Krajevni ljudski odbor Pevno

- Vovk, Anton. V spomin in opomin. Osebni zapisi škofa Antona Vovka od 1945 do 1953. Uredil Blaž Otrin. Ljubljana: Družina, 2008.

34 Usp. Farne spominske plošče, 1, uredil Branko Rozman (Ljubljana: Družina, 1995); Farne spominske plošče, 2, uredil Janez Gril (Ljubljana: Družina, 2000); Farne spominske plošče, 3, uredila Anton Drobnič, Franc Popek i Jožef Kočar (Ljubljana: Družina, 2012).

${ }^{35}$ Njemačka vojna groblja iz Drugoga svjetskog rata uređena su u Sloveniji u Celju, Kranju i Ljubljani (Žale). Usp. Volksbund Deutsche Kriegsgräberfürsorge e. V. / Kriegsgräberstätt. http://www.volksbund. de/kriegsgraeberstaetten. html (pristupljeno 8. 10. 2014.). 
- Benedik, Franc. „Nemško vojaško pokopališče v Kranju“. Kranjski zbornik 2000, (2000), 250-259.

- Črnej, Janez. Grobišča na Štajerskem. Ljubljana: Samozaložba, 2009.

- Deželak Barič, Vida. „Posledice vojnega nasilja. Smrtne žrtve druge svetovne vojne in zaradi nje na Slovenskem". U: Nasilje vojnih i povojnih dni. Uredila Nevenka Troha, 11-46. Ljubljana: Inštitut za novejšo zgodovino, 2014.

- Dolinar, France Martin. „Duhovniki v primežu revolucije“. U: Žrtve vojne in revolucije. Zbornik. Uredniški odbor Janvit Golob, Peter Vodopivec, Janko Prunk i Milena Basta, 61-69. Ljubljana: Državni svet Republike Slovenije, 2005.

- Farne spominske plošče, 1. Uredil Branko Rozman. Ljubljana: Družina, 1995.

- Farne spominske plošče, 2. Uredil Janez Gril. Ljubljana: Družina, 2000.

- Farne spominske plošče, 3. Uredila Anton Drobnič, Franc Popek i Jožef Kočar. Ljubljana: Družina, 2012.

- Ferenc, Mitja. „'... Grobovi so zravnani in zaraščeni' (Seznam grobov sovražnikovih vojakov padlih iz časa 2 . svetovne vojne na območju občine Ilirska Bistrica)“. Prispevki za novejšo zgodovino, št. 1, (2004), 160-168.

- Ferenc, Mitja. „Taborišče Teharje in prikrita grobišča v Sloveniji“. U: Iz zgodovine Celja 1941-1945. Glavna urednica Marija Počivavšek, 215-248. Celje: Muzej novejše zgodovine, 2004.

- Ferenc, Mitja. „Zamločana grobišča Druge svetovne vojne v Sloveniji“. U: Totalitarizmi na Slovenskem $v$ 20. stoletju. Zbornik slovenskih prispevkov $z$ javne tribune $z$ naslovom Zločini totalitarnih režimov, ki je potekala 8. aprila 2008 v prostorih Evropske komisije v Bruslju. Uredil Damjan Hančič, 142152. Ljubljana: Študijski center za narodno spravo, 2010

- Ferenc, Mitja. Kočevska pusta in prazna. Nemško jezikovno območje na Kočevskem po odselitvi Nemcev. Ljubljana: Modrijan, 2005.

- Ferenc, Mitja. Prekopi žrtev iz prikritih grobišč (1991.-2011). Ljubljana: Znanstvena založba Filozofske fakultete, 2012.

- Ferenc, Mitja. Prikrito in očem zakrito. Prikrita grobišča 60 let po koncu druge svetovne vojne. Celje: Muzej novejše zgodovine, 2005.

- Ferenc Mitja, i Želimir Kužatko. Prikrivena grobišta Hrvata u Republici Sloveniji/Prikrita grobišča Hrvatov $v$ Republiki Sloveniji/Hidden Croatian Mass Graves in the Republic of Slovenia. Zagreb: Počasni bleiburški vod, 2007.

- Ferenc Mitja, Gojko Zupan, i Mateja Bavdaž. Pokopališča in nadgrobniki kočevskih Nemcev/Friedhöfe und Grabsteine der Gottscheer Deutschen/Cemeteries and Tombstones of the Gottscheer Germans. Ljubljana: Zavod za varstvo kulturne dediščine Slovenije, 2002.

- Geiger, Vladimir. „Nekoliko podataka o uklanjanju vojnih grobalja i grobova 'okupatora' i 'narodnih neprijatelja' u Bosni i Hercegovini nakon Drugoga svjetskog rata“. Politički zatvorenik, br. 262, (2015), 24-26. 
- Geiger, Vladimir. „Nekoliko podataka o uklanjanju vojnih grobalja i grobova 'okupatora' i 'narodnih neprijatelja' u Bosni i Hercegovini nakon Drugoga svjetskog rata (II.)“. Politički zatvorenik, br. 263, (2015), 18-21.

- Geiger, Vladimir. „Nekoliko podataka o uklanjanju vojnih grobalja i grobova 'okupatora' i 'narodnih neprijatelja' u Vojvodini nakon Drugog svjetskog rata“/„Einige Tatsachen über das entfernen von Militärfriedhöfen und Gräbern der 'Okkupatoren' und 'Staatsfeinde' in Wojwodina nach dem Zweiten Weltkrieg“. Fenster, br./Nr. 17, (2015), 12-15/16-19.

- Geiger, Vladimir. „O uklanjanju vojnih grobalja i grobova 'okupatora' i 'narodnih neprijatelja' u Sloveniji nakon Drugog svjetskog rata“. Politički zatvorenik, br. 264, (2015), 29-32.

- Geiger, Vladimir. „O uklanjanju vojnih grobalja i grobova 'okupatora' i 'narodnih neprijatelja' u Sloveniji nakon Drugog svjetskog rata (II.)“. Politički zatvorenik, br. 265, (2015), 38-42.

- Geiger, Vladimir. „Odluka o uklanjanju grobalja i grobova 'okupatora' i 'narodnih neprijatelja' Ministarstva unutarnjih poslova DF Jugoslavije od 18. svibnja 1945“. Politički zatvorenik, br. 257, (2014), 34-39.

- Geiger, Vladimir. „Odluka o uklanjanju grobalja i grobova 'okupatora' i 'narodnih neprijatelja' Ministarstva unutarnjih poslova DF Jugoslavije od 18. svibnja 1945. (II.)“. Politički zatvorenik, br. 258, (2014), 29-34.

- Geiger, Vladimir. „Odluka o uklanjanju grobalja i grobova 'okupatora' i 'narodnih neprijatelja' Ministarstva unutarnjih poslova DF Jugoslavije od 18. svibnja 1945. (III.)“. Politički zatvorenik, br. 259, (2014), 12-17.

- Geiger, Vladimir. „Odluka o uklanjanju grobalja i grobova 'okupatora' i 'narodnih neprijatelja' Ministarstva unutarnjih poslova DF Jugoslavije od 18. svibnja 1945. i Katolička crkva u Jugoslaviji“. Tkalčić, br. 18, (2014), 387-426.

- Geiger Vladimir, i Slađana Josipović Batorek. „O provođenju odluke komunističkih vlasti iz 1945. o uklanjanju grobalja i grobova 'okupatora' i 'narodnih neprijatelja' u Slavoniji i Srijemu". Scrinia slavonica, sv. 15, (2015), 291-316.

- Hubad, Jože. „Orlov vrh - simbol slovenstva“. Zaveza, št. 13, (1994), 59-61.

- Jamnik, Pavel. „Zavedanje zločina. Začetki policijskega in tožilskega preiskovanja nezastarljivih zločinov, storjenih po koncu 2. svetovne vojne $\mathrm{v}$ Sloveniji“. U: Totalitarizmi - vprašanja in izzivi. Ob dvajsetletnici padca železne zavese $v$ Evropi. Zbornik prispevkov $z$ mednarodnega posveta 9. novembra 2009. v Ljubljani. Uredila Mateja Čoh, 95-112. Ljubljana: Študijski center za narodno spravo, 2009.

- Lopičić-Jančić, Jelena Đ. Krivičnopravna zaštita ratnih zarobljenika u jugoslovenskom krivičnom pravu. Beograd: IP „Vaša knjiga“ d. o. o., 2005.

- Maček, Janko. „Ob 70-letnici spominske kapelice prve in druge svetovne vojne ter revolucije v Rovtah“. Zaveza, št. 94, (2014), 13-22.

- Maček, Janko. „Revolucija jim je zadala neozdravljive rane“. Zaveza, št. 79, (2010), 16-24.

- Mikola, Milko. Rdeče nasilje. Represija $v$ Sloveniji po letu 1945. Celje - Ljubljana: Mohorjeva družba, 2012.

- „Na Orlovem vrhu zadnjem počivališču slovenskih junakov. Slike s spominskih žalnih slovesnosti na praznik Vseh svetih leta 1944.”/„Gedenkfeier auf Orlov vrh. Der letzte Grabstätte slowenischer Helden Aufnahmen von 
don Feierlichkeiten am Allerheillgentag 1944 auf dem Ehrenfriedhof am Schloßberg“. Slovensko domobranstvo, št. 8, (1944), 4-5.

- „Odkritje spomenika padlim v Rovtah“/„Eröffnung einer Heldengedenkstätte in Rovte". Slovensko domobranstvo, št. 8, (1944), 6.

- Perme, Franc. „Zamolčani grobovi in njihove žrtve“. U: Slovenija. Zamolčani grobovi in njihove žrtve 1941-1948. Zbornik. Uredniški odbor Franc Perme, Anton Žitnik, i Davorin Žitnik, 66-75. Ljubljana - Grosuplje: Društvo za ureditev zamolčanih grobov, 1998.

- Petković, Boško. Međunarodne konvencije o ratnom pravu. Zagreb: Sveučilišna tiskara d. o.o., 1992.

- Podberšič, Renato. Revolucionarno nasilje na Primorskem. Goriška in Vipavska 1941-1945. Ljubljana: Studijski center za narodno spravo, 2011.

- Vučinić, Zoran. Međunarodno ratno i humanitarno pravo. Beograd: Službeni glasnik, 2006.

- "Zakon o pokopališki in pogrebni dejavnosti“. Uradni list Socijalistične Republike Slovenije, št. 34, 19. XI. 1984, 1875-1879.

- Volksbund Deutsche Kriegsgräberfürsorge e. V. / Kriegsgräberstätt. http://www.volksbund. de/kriegsgraeberstaetten. html

Vladimir Geiger

THE IMPLEMENTATION OF THE DECISION FROM MAY 18, 1945

DEALING WITH THE REMOVAL OF MILITARY GRAVEYARDS AND GRAVES OF „OCCUPIERS“ AND „PEOPLE'S ENEMIES“ IN SLOVENIA

\section{Summary}

Immediately after the end of World War II Yugoslav communists took various measures to completely and radically liquidate their enemies. One of these measures was a decision of the Ministry of Internal Affairs of the Democratic Federative Yugoslavia from May 18, 1945 to remove the graveyards and individual graves of fallen "occupying" soldiers and of "people's enemies". This measure was concerning the graves and memorial monuments of German, Italian and Hungarian soldiers, as well as members of Ustasha, Chetnik and Slovenian Home Guard units. Removal of graveyards and individual graves of „occupiers" and „people's enemies" was conducted thoroughly in Slovenia. This can be proven by available documents and witnesses of these events as well as by the present day conditions of graveyards localities. Destruction of military graveyards of „enemies“ was conducted in Yugoslavia not only in the immediate postwar period, but also later. Even during the late 1980s State Security service observed locations of unmarked graves, especially those better known, in order to identify all those who visited these locations where during the war and immediately after „enemy” soldiers and civilians were executed and buried. After the World War II, graves and graveyard of kil- 
led partisans as well as graves and graveyards of the "victims of fascist terror" were protected according to the law, taken care of and maintained. Graves and graveyards of „enemy" soldiers and graves of those who „collaborated with the occupying powers" were outside the law. The situation remained unchanged until the dissolution of the Socialist Federative Republic of Yugoslavia.

KEYWORDS: Slovenia, 1945, Decision to remove the graveyards and individual graves of "occupiers" and "people's enemies“, Communist repression

\section{EXECUTION DER ENTSCHEIDUNG VOM 18. MAI 1945 ÜBER DIE BESEITIGUNG VON MILITÄRISCHEN FRIEDHÖFEN UND GRÄBERN DER „OKKUPANTEN“ UND „VOLKSFEINDE“ IN SLOWENIEN}

\section{Zusammenfassung}

Auf die völlige und radikale Abrechnung der jugoslawischen Kommunisten mit ihren Feinden unmittelbar nach dem Ende des Zweiten Weltkrieges zielte auch die Entscheidung des Innenministeriums der Demokratischen Föderativen Republik Jugoslawien vom 18. Mai 1945 über die Beseitigung von Friedhöfen und Gräbern der „Okkupanten“ und „Volksfeinde“ ab, die sich auf die Friedhöfe und Grabsteine von Soldaten der deutschen, italienischen und magyarischen Armee sowie von Ustascha, Tschetniks und Mitgliedern der slowenischen Landwehr (domobrani) bezog. Erhaltene Dokumente und Zeitgenossen dieser Ereignisse, aber auch Zustand dieser Friedhöfe zeugen davon, dass die genannte Entscheidung über die Beseitigung von Friedhöfen und Gräbern der „Okkupanten" und „Volksfeinde" auch in Slowenien systematisch durchgeführt wurde. Die Gräber der militärischen „Feinde“ wurden in der Sozialistischen Föderativen Republik Jugoslawien nicht nur in der unmittelbaren Nachkriegszeit, sondern auch später demoliert. Der Staatliche Sicherheitsdienst in Slowenien ging sogar bis gegen Ende der 1980-er Jahre in der Nähe von unmarkierten Gräberfeldern, und vor allem in der Nähe der bekanntesten von ihnen, jenen Leuten nach, die die Plätze mit sterblichen Überresten der während des Zweiten Weltkrieges und in der unmittelbaren Nachkriegszeit ermordeten „Feinde“ - Soldaten und Zivilisten - besuchten. Nach dem Zweiten Weltkrieg wurden die Friedhöfe und Gräber der gefallenen Partisanen und der Opfer des "faschistischen Terrors" in Jugoslawien und Slowenien gesetzlich geschützt und gepflegt, während die Friedhöfe und Gräber der "feindlichen“ Soldaten und der „Kollaborateuren der Okkupanten“ vom Gesetz ausgeschlossen blieben. So blieb es bis zum Zerfall der Sozialistischen Föderativen Republik Jugoslawien.

SCHLÜSSELWÖRTER: Slowenien, 1945, Entscheidung über die Beseitigung von Friedhöfen und Gräbern der „Okkupanten“ und „Volksfeinde“, kommunistische Repression 